https://helda.helsinki.fi

\title{
Bicycle model on climate change education : presenting and evaluating a model
}

\section{Cantell, Hannele}

2019-05-04

Cantell , H , Tolppanen , S , Aarnio-Linnanvuori , E \& Lehtonen , A 2019 , ' Bicycle model on climate change education : presenting and evaluating a model ' , Environmental Education Research , vol. 25 , no. 5 , pp. 717-731 . https://doi.org/10.1080/13504622.2019.1570487

http://hdl.handle.net/10138/318082

https://doi.org/10.1080/13504622.2019.1570487

unspecified

acceptedVersion

Downloaded from Helda, University of Helsinki institutional repository.

This is an electronic reprint of the original article.

This reprint may differ from the original in pagination and typographic detail.

Please cite the original version. 


\section{Bicycle model on climate change education: presenting and evaluating a model}

Cantell, Hannele ${ }^{1}$, Tolppanen, Sakari², Aarnio-Linnanvuori, Essi ${ }^{3}$ and Lehtonen, Anna4

${ }^{1}$ Corresponding author

Address: University of Helsinki, P.O.Box 9, 00014 University of Helsinki, Finland +35850 4904176, hannele.cantell@ helsinki.fi, orcid.org/0000-0003-4675-1881

${ }^{2}$ Address: University of Eastern Finland, Futura, Joensuu, Finland

3 Address: WWF Finland, Lintulahdenkatu 10, 00500 Helsinki, Finland

+358505114397 essi.aarnio-linnanvuori@wwf.fi

4 Jukolanahde 2d17, 02180 Espoo, Finland

+358405403821, annaelehtonen@gmail.com

\section{Biographical note}

${ }^{1} \mathrm{Ph} . \mathrm{D}$. Hannele Cantell is working as a university lecturer of geography education in University of Helsinki, Faculty of Educational Sciences. She is an adjuct professor (the title of docent). Her research interests are climate education, global education, geography education and phenomenon-based learning.

$2 \mathrm{Ph}$.D. Sakari Tolppanen is working as a researcher at the University of Eastern Finland in the School of Applied Educational Science and Teacher Education. His research interests are climate change education, sustainability education and non-formal education.

${ }^{3}$ Ph.D. Essi Aarnio-Linnanvuori is an experienced environmental educator, who has a $\mathrm{PhD}$ from Environmental Change and Policy, University of Helsinki. Her research interests relate to the 'wickedness' of environmental issues. She has a particular interest in interdisciplinary and trans-disciplinary environmental education, and climate change education. She currently works as an education officer at WWF Finland.

4 M.Ed. Anna Lehtonen is doing doctoral research of arts-based climate change education at the University of Helsinki, Finland. She applies drama as a participatory research method for 
socially constructed response to climate change. Her research interests include climate change education, drama as a research method and education for a sustainable future.

\section{Introduction}

As climate change has become one of the world's biggest environmental challenges, countries have become increasingly aware of the importance of climate change education (Ratinen 2016; Schreiner, Henriksen \& Hansen 2005). However, climate change is a wicked problem with no simple solutions (Incropera 2016). For that same reason, climate change education can also be described as a wicked problem.

Although climate change is strongly present in current politics, economics, and pedagogy, studies have found climate change education often incomplete and narrow-minded (e.g., Lehtonen \& Cantell 2015). Traditionally, climate change is only dealt with in natural sciences, particularly biology and geography. However, to understand the implications of climate change and to promote climate-responsive action, it is also necessary to understand social sciences, health sciences, and politics (Hens \& Stoyanov 2014). In addition, ethical and humanistic perspectives must be taken into account in climate change education, as the topic raises strong feelings such as guilt, hopelessness, helplessness, and even anger (see, e.g., Pihkala 2017; Hicks 2014).

Several studies have found that teachers' knowledge of climate change is deficient and fragmented, and that teachers have many misconceptions (Ratinen 2016; Lombardi \& Sinatra 2013; Andersson \& Wallin 2000). Furthermore, integrating multidisciplinary climate change education into schools is challenging, as many teachers continue to see climate change quite narrowly, mainly as an issue related to natural sciences (Aarnio-Linnanvuori 2016; 2018; Wise 2010). 
During the past few decades, several different models have been developed to describe the objectives and special features of environmental and sustainability education (e.g., Tolppanen 2015; Koskinen \& Paloniemi 2009; Palmer 1998; Hungerford \& Volk 1990). Many of these models emphasize the importance of environmental knowledge and skills, as well as the importance of environmental activity, experiences, and attitudes. One of the bestknown environmental education models was created by Joy Palmer (1998). This so-called 'tree model' is based on formative influences (roots and trunk) and highlights three forms of education (leaves): education in or from environment, education about environment, and education for environment (Palmer 1998, 272).

However, environmental and sustainability education models do not, as such, suffice to meet the needs of depicting climate change education, as they do not sufficiently reflect the broad scope of climate change. This is understandable, as they were created to depict environmental or sustainability education on a general, not a specific, level. Due to their general nature, they do not meet the more specific needs of a particular environmental or sustainability issue, such as climate change. However, to our knowledge, models for holistic climate change education are nonexistent. Researchers such as Shepardson et al. (2012) have modeled the important scientific aspects of climate change education, and a large amount of literature exists on what aspects should be considered in climate change education. However, this information is somewhat scattered and has not been knit together in a visual and a coherent way. For this reason, the first aim of this article is to present a model for climate change education: the bicycle model. The model was first published in Finnish to depict the holistic nature of climate change education in a way that can be easily visualized and understood (Tolppanen, Cantell, Aarnio-Linnanvuori \& Lehtonen, 2017). The second aim is to evaluate the usefulness of the model with research data gathered from climate change education experts. 


\section{The bicycle model for climate change education}

The climate change education model (Figure 1) is presented as a bicycle because climate change education, like a bicycle, is one entity that requires all of its parts to function together. Furthermore, a bike is not meant to stay still, but rather, needs a user to be in constant motion. Finally, as a visual presentation, the model and the metaphor are easy to remember as almost everyone is familiar with the parts of a bicycle. In addition, a bicycle is considered an environmentally conscious way to travel too. The bicycle model was built by examining what aspects previous literature has highlighted as the essential aspects of climate change education and putting these pieces together to form one entity. A summary of the literature is presented below.

Figure 1 here. The bicycle model for holistic climate change education. Tolppanen et al., 2017.

\section{Wheels: knowledge and thinking skills}

Wheels are essential for a bike to move forward. Without them a bicycle is not a bicycle. Therefore, in the climate change education model, the wheels depict knowledge and thinking skills, which are necessary for climate change education. Though knowledge is essential, gaining more knowledge should not be the aim of climate change education, but rather, a means to an end. Environmental information should also be analyzed critically and used to gain deeper understanding. According to Shepardson et al. (2012), at least the following aspects of knowledge should be studied in climate change education: (i) natural causes and changes in the climate system, (ii) atmosphere and pollution, (iii) amounts of snow and ice, (iv) oceans (sea level, temperature and life), (v) soil and vegetation, and (vi) impact on humans. They also point out that it is essential to understand the environment as a system and have a certain level of understanding of feedback loops that occur. 
In addition to scientific knowledge, climate change education should highlight that the consequences of climate change are uncertain and impact different regions and people in different ways (Andrey \& Mortsch 2000). Therefore, in order to understand the challenges of climate change mitigation and adaptation, information on human behavior and on political and economic impacts are needed. In the context of climate change, it is also essential to highlight the central role of media as communicators and modifiers of attitudes (Incropera 2016; González-Gaudiano \& Meira-Cartea 2010; Schreiner et al 2005). Tolppanen and Aksela (2018) also point out that gaining knowledge of the possibilities and limitations of technical solutions is important to students.

However, climate-related information alone is worthless if it is not used, applied, or critically evaluated. For this reason, the two wheels of the model-knowledge and thinking skills — are the same size. Thinking skills can be developed by reflecting on values, exploratory learning, acting for the environment, and comparing different types of texts on a particular issue (MacMillan \& Vasseur 2010). Furthermore, since climate change has many political and economic connections, it is important to be aware of and discuss intentions to spread information. It has also been argued that using scientific data to examine texts that question the reality of climate change both promotes critical thinking skills and influences how students perceive climate change (Lombardi, Sinatra \& Nussbaum 2013). In summary, climate change education should be taught to help students: (i) think critically, systematically, and appropriately, (ii) tolerate uncertainty, (iii) assess values and behavioral habits of the students and their surrounding society, (iv) create and reflect on alternative future scenarios, and (v) affect their own and society's future (Hicks 2014; Lombardi, Sinatra \& Nussbaum 2013).

One way to build knowledge and thinking skills is through systems learning. Systems learning creates connections between concepts and different phenomena to help deal with 
complex entities. The goal is a holistic approach that combines scientific understanding of the climate change phenomenon with knowledge of humanist-societal causes and consequences (see Salonen 2010).

\section{Frame: identity, values, and worldview}

The identity, values, and worldview of a learner create the foundation for climate change education. New knowledge and skills will also be attached to the frame they form. Climate change raises issues related to humanity, society, culture, and ethics that are often excluded in education (Selby 2010). However, students are often interested in the ethical issues of climate change and show a desire to look at environmental issues from many different perspectives (Tirri, Tolppanen, Aksela \& Kuusisto 2012). The wicked nature of climate change is reflected in conflicts of value. The discussion on values should be comprehensive, at least from the point of view of human dignity and equality: should everyone, for example, have the same opportunities for success and prosperity, and if so, why are we depriving each other? (Tolppanen \& Aksela 2018, Tolppanen et al., 2017)

Increasingly central to climate change education is thinking about the role and identity of human beings as consumers and as the ones who cause environmental problems. It is also essential to ask whether students are given the opportunity to act towards climate change mitigation (Tolppanen et al., 2017) and to consider what is termed as 'sustainability' and 'well-being' in climate change education. Many, including teachers themselves, hope for sustainable development but do not want to give up their own habits or consuming lifestyle (Ratinen 2013). Therefore, in addition to thinking about what people want to keep, in climate change education it is at least as important to think about what they are willing to give up.

\section{Chains and pedals: action to curb climate change}


Knowledge and thinking skills need to transfer into practical action. In the model this is depicted through the bicycle's chains and pedals. The pedals also symbolize action in the sense that pedaling typically requires some level of effort. In this context, activity means activity on 'real life' issues. A learner will be able to participate in climate change mitigation when encouraged and guided.

Kollmuss and Agyeman (2002) emphasize that environmental action is related to not only knowledge of a topic, but also empathy, a desire to help, other people's opinions, societal norms, and ease of action. People's motivation is also influenced by the time and cost of doing and how actively environmental issues are thought of (Degerman 2016; Kallgren \& Wood 1986). However, increasing pro-environmental action is complicated and requires longterm work and planning, as the changing needs of climate change are not the same in all communities and regions.

\section{Saddle: motivation and participation}

The bicycle does not move without a cyclist. However, the bicycle will not be used if it is difficult to sit on the saddle. The saddle thus affects the cyclist's motivation. Research has shown that young male students especially do not view climate change as their problem, nor do young students feel that they can affect climate change mitigation (Degerman 2016). In order for climate change education to motivate, the topic should not be described as a distant issue or something too complicated to understand. Rather, it is essential to emphasize that people have built our society — and therefore, we can change it as well.

Though the model only contains one bicycle to keep it simple, the key to climate change mitigation and adaptation is to work together. One reason is that the opinions of others can play a strong role in maintaining motivation (Kollmuss \& Agyeman 2002). Therefore, it is important that students are offered opportunities to participate in joint positive action and 
encouraged to support each other's involvement (Koskinen \& Paloniemi 2009). School is a good place to strengthen community and to practice positive engagement. Motivation and inclusion can also be supported by structural solutions. For example, school principals and municipalities play an important role in how sustainable development values are attained in school (Uitto, Boeve-de Pauw \& Saloranta 2014).

\section{Brakes: operational barriers}

To promote environmental responsibility, it is essential to understand what hampers action. According to Cantell and Larna (2006), barriers to environmental responsibility are often human tendencies such as desire for comfort, laziness, force of habit, and haste. It is therefore not necessarily a lack of environmental knowledge or activity, even though these may have an effect. Environmental responsibility is also hampered by structural reasons, such as the lack of a functioning infrastructure like a public transport network. Money—or the lack

of it - is also often a barrier to climate-responsive behavior. Lack of action towards climate change mitigation is also caused by various psychological and socio-cultural barriers, such as denying the problem, social norms, and uncertainty about the effectiveness of one's own actions (Norgaard 2011; Gifford 2011). In addition, top-down instructions and blame may cause a decrease in the willingness to act.

\section{Lamp: hope and other emotions}

Climate change may raise strong emotions, which, in the bicycle model, are depicted as a lamp showing the way forward. Studies have found that many students experience strong feelings towards climate change, such as worry, fear, sadness, guilt, hatred, and hopelessness. Also, teachers' negative attitudes and feelings, such as fear and uncertainty, are linked to students' attitudes and capacity-building (Hermans 2016; Ojala 2015). 
The underlying reason for ignorance towards climate change may in fact be caused by people not wanting to deal with challenging feelings that this depressing issue raises in them and others. In addition, teachers may avoid issues related to climate change in their teaching, as they think that dealing with emotions belongs to therapists, not teachers (Pihkala 2017). However, emotions have a significant impact on learning and should therefore be considered in climate change education.

Instead of negativity, climate change education should stimulate hope and compassion in people. For this reason, the bicycle model has highlighted the importance of hope in particular. Even if teachers do not have ready answers to climate issues, sharing ideas and searching for answers to challenging questions brings hope (Hicks 2014). Hope is strengthened when one realizes that even a difficult issue can be solved, and steps are taken towards solving it. Hope can help increase well-being, as well as drive other feelings (Snyder et al. 2002). However, it is essential to make a distinction between optimism and hope. Optimism is often associated with an idea that everything is OK, despite the realities. An optimistic idea of everything being OK can prevent people from making the necessary choices for change to take place (Pihkala 2017). Realistic hope, on the other hand, is built only after one has faced different challenges in the world, but despite seeing these challenges, is able to believe in one's own influence (Pihkala 2017; Hicks 2014; Orr 2009).

\section{Handlebar: future orientation}

Envisioning the future is a key component of climate change education. Education should provide ways to look at the future critically, but in a positive light. This is a challenge in education, as many climate change scenarios provide a dark picture of the Earth's future. Furthermore, the complexity of the phenomenon makes it difficult to sketch scenarios. However, students should practice decision-making, even when its accuracy is not fully 
assured (see, e.g., Sterling 2010). To accomplish this, the integration of information and arts could be helpful, because future thinking requires creativity and arouses a wide range of emotions (Hicks 2014).

\section{Data collection and analysis}

The aim of this research was to examine climate change education experts' perceptions of climate change education and the bicycle model to present it. Secondly the study examined how the model could be developed further. The research data was gathered in two ways: first, with a documented group discussion and second, with an electronic questionnaire.

\section{Group discussion}

The group discussion took place in December 2017 at a seminar organized by Sirene (Interdisciplinary network of environmental and sustainability education research in Finland). The group consisted of 11 members who represented climate and sustainability educators and researchers, in addition to schoolteachers. The group participants had published scientific articles on environmental education, been involved in NGOs that advance environmental education, or done above-standard projects with their students on environmental issues.

In the seminar, the participants were asked to describe the forms of climate change education they studied or practiced in their work. They were then shown the bicycle model and asked to reflect on it with their practical work. In their reflections, the participants highlighted the most important aspects of climate change education based on the bicycle model. They also gave valuable suggestions on how to develop the model further. The group 
also reflected on the usefulness of the model in practical teaching, learning, and planning situations.

The researchers took notes on the discussion and examined their findings after the session to ensure they agreed on what had been discussed. The participants' answers were cross-analyzed by the researchers using qualitative content analysis. The group discussion also gave an important perspective for the researchers to include questions in the questionnaire.

\section{Questionnaire}

To gather further insight and to increase the reliability of the previous findings, a questionnaire was sent out to a selected group of environmental educators, planners, and researchers who are known to be involved with climate change education in Finland. Only one of the experts was also in the discussion group. The main aim of the questionnaire was to gather data to understand what perceptions these experts have on climate change education and how well they think the bicycle model presents the relevant dimensions of climate change education. Before sending the questionnaire, researchers examined the participants' merits and activity in climate change education; only those they considered experts were sent the questionnaire. The criteria for selecting the experts were the following: (i) master's or doctoral degree, (ii) many years' experience in research or environmental education, especially climate education, and (iii) being well-known and professionally respected in the environmental education community in Finland. The environmental artists were an exception to the academic requirement, but they were professionally well-known and accomplished. To ensure validity of the selection, the researchers checked and discussed with each other the experts' merits and activity to ensure that they agreed. 
The questionnaire was sent out in January 2018 to 30 experts, as well as to the mailing list of the Finnish climate change panel, allowing all panel members to participate. A total of 17 experts participated and answered the survey: 3 sustainability and climate change education researchers, 6 schoolteachers (representing primary, secondary, and upper secondary levels), 2 climate educators (working in NGO's), 3 environmental artists, and 3 planners and coordinators (working in environmental organizations).

The survey consisted of background questions and two sets of questions related to two themes. The first set of questions focused on the respondents' views on the content of climate change education and the bicycle model. In this set of questions, the respondents were asked to name the three aspects of the bicycle model they considered most important and the three they considered least important. They were then asked to justify their selections. In the questionnaire, all of the experts selected the three aspects that they considered most important, but most failed to mention the three they considered least important. The second set of questions examined the respondents' opinions of the usefulness of the bicycle model in the context of climate change education, especially in planning and implementing climate change education. The aim was to find out if respondents thought they would use the model in their work. Finally, the respondents were asked to give open feedback on how the model could be developed.

The questionnaire consisted of both structured and open-ended questions. Researcher triangulation was used to start the analysis of the open-ended responses. All four authors of this article first read all the answers and made their own categorizations of the data. They found different ways to construct themes, but there was also a remarkable similarity of issues identified. These were then discussed together until a consensus on data analysis was reached.

\section{Results}


Although the data from the group discussions was gathered first, this section first presents the data collected by the questionnaire. The reason is that the questionnaire consists of more fundamental data about climate change education and the bicycle model, whereas the discussion material helped formulate the questionnaire, and mainly contained comments that strengthen the findings of the questionnaire. In addition, the group discussion gave valuable ideas about how to develop the model. The results are shown in Table 1.

Table 1 here.

Selecting between the parts of the bicycle was found to be difficult for some of the respondents. Several experts stated that the selection was practically impossible, and they restated that education needs to be holistic. They considered all the parts connected to each other: 'All eight parts are tightly connected to each other. [...] Values, emotions, and motivation guide action, knowledge is necessary for thinking skills and recognizing barriers of action, and so forth.' (E10) On the other hand, because of this connectedness, some respondents suggested integrating some parts (e.g., barriers, future orientation) into others.

\section{Most valued aspects of climate change education}

As Table 1 shows, it was most common for experts to view motivation and participation, knowledge of climate change, action to curb climate change, and hope and other emotions as the top priorities of climate change education. Motivation and participation were chosen as the most important parts of the bicycle model. Unlike knowledge, motivation was not viewed as a starting point, nor an ending point, of climate change education. Rather, it was seen as playing an important role in the whole process, intertwining strongly with other aspects of climate change education. One expert described this in the following words: 'It is 
possible to ride a bicycle standing up (=action), without a saddle (=motivation), but that way you won't have the strength to go very far and you will not see lasting results. That is why awakening motivation is important in climate change education, and education in general. It helps create long-lasting action. Getting someone motivated is like lifting a bicycle to the top of a hill and letting them ride downhill. They will first gain momentum even without pedaling. This way the students get an initial boost of action, giving them a desire to keep pedaling, to keep the motion.' (E9)

Experts believed that motivation can be increased through knowledge and action. However, they also pointed out that our school system is built in a way that may stifle motivation towards wicked problems, such as climate change. According to one of the experts, 'Motivation is one of our biggest challenges. How to awaken and maintain motivation if and when our school system still focuses on preparing students to their matriculation examinations and does not put strong emphasis in solving wicked problems.' (E13)

Many experts also prioritized the importance of knowledge of climate change but seemed to have mixed reasons to do so. Some of them viewed knowledge as a starting point of holistic climate change education: 'Climate change education is challenging if it is not based on a basic understanding of climate change. It is hard to deal with the issue, if knowledge is bypassed.' (E4) However, other experts seemed to view knowledge as a foundation, which, if mastered, would lead to positive action. For instance, one wrote: 'It is important that students are knowledgeable on the cause and effect of climate change, so that they can act deliberately and logically regarding climate change mitigation and adaptation.' (E11) Furthermore, some experts seemed to emphasize this aspect due to practical reasons: 'Climate knowledge is most related to biology and geography, the subjects I teach.' (E8) 
Interestingly, none of the experts who prioritized knowledge selected values as one of the top three aspects they prioritize. Rather, they usually emphasized the importance of motivation and participation, action and thinking skills.

Environmental activity, or action to curb climate change, was also seen as one of the most important aspects of climate change education. The experts highlighted that environmental activity indicates hope and empowerment: People who take positive environmental actions probably also have a positive future orientation. To act for the environment, however, is not automatic but rather, needs to be practiced. This is a challenge for environmental education: 'In climate change education participation is built on action. We have a chance to have an influence on things and act for a better planet. Activity also promotes positive attitudes towards the future, and also creates empowerment.' (E4)

Nine of the experts mentioned hope and other emotions among the most important elements of climate change education. Emotions were described as a hindrance or a challenge for learning and, in general, an unfamiliar area among teachers. Experts related emotions to action and agency. One described the role of emotions as 'working like a glue in learning, how the information becomes attached in the memory'. (E5) Most of the experts who regarded emotions as important also prioritized motivation and participation. One respondent observed that 'hope is a lamp and an engine' (E4), and another described personal motivation as 'an engine' (E6) for successful climate change education promoting action. Emotions were also highlighted as a problematic aspect of education: 'Having focus on negative issues might depress and prevent from learning and especially from taking action. On the other hand, according to research, negative emotions are strongly related to the desire of climate change mitigation. The positive message of progress of climate change mitigation might have an opposite effect, diminishing motivation to act.' (E8) However, hope and other emotions were regarded as crucial aspects and challenges of climate change education in the future: 'If a 
person feels total hopelessness in front of climate change, most likely he or she gives up rather than aims at action.' (E10)

\section{Least valued aspects of climate change education}

The experts were asked to name three aspects of climate change education that they considered least important. In the questionnaire, they were also asked to determine which parts of the model they emphasized least in their own work. However, most of the experts failed to name three parts. Over half $(\mathrm{N}=10)$ of them picked only one part of least importance. As one expert said, 'I cannot choose more than one, and even that one I pick only because I have to.' (E12)

Dealing with barriers of climate change was considered to be the least important aspect of climate change education. Nine experts pointed to this. Furthermore, this was the only aspect that received a significant number of votes (see Table 1). Experts justified this decision by saying that dealing with barriers can be included in other parts of the bicycle, namely action, emotions, and values. Several experts also mentioned practical reasons, such as time constraints, as a reason why they didn't consider dealing with barriers of climate change as important. The justification was that the focus of climate change education ought to be positive action rather than dealing with barriers: 'It is easier and more inspiring to concentrate on the possibilities of action than on what is not done.' (E4) Furthermore, experts felt that people were already aware of the barriers or at least will become aware when dealing with climate change-related solutions. 'Time is limited and I don't want to concentrate on barriers. I understand that dealing with barriers is useful, but adults consider these selfevident.' (E7) Finally, some experts also felt that barriers were dealt with implicitly. 
Thinking skills and knowledge of climate change were also low on the priority list.

Five experts mentioned thinking skills as a less important aspect of climate change education. However, rather than viewing thinking skills as unimportant, they argued that these were already built into learning and education, rather than being a distinct part of climate change education: 'Thinking skills, values, worldview, and identity, these are [...] big things and would need a long education process.' (E4) Four experts viewed climate knowledge to be low on their priority list because they believed that there was already an abundance, or overabundance, of knowledge available. For instance, a science teacher wrote: 'Teaching climate knowledge is not a priority for me, because it is a given and a traditional part of climate change education. Knowledge will continue to be distributed even though its role in climate change education and climate communication would decrease significantly.' (E1) In the same way, a few other experts believed that dealing with climate knowledge was taken care of by other teachers and the media. An expert with a research background in ecotheology wrote: '[I don't prioritize teaching] climate knowledge because I leave that aspect to the scientists.' (E15)

Even though the experts were first asked a general question on the three least important aspects of climate change education, and then a specified question considered this same issue from the view of their own profession, it was evident that both questions were answered from the viewpoint of their profession. As an example, an expert working in a natural history museum justified her choice of choosing values, identity, and worldview as the least important aspect by the limitations of a museum visit: 'During a short [natural history museum] visit it is not possible to begin with such deep themes as these'. (E6) Therefore, the answers to the question of least valued aspects do not seem to reflect the experts' view of climate change education in general, but rather, their possibilities to implement that aspect as professionals. 


\section{Usefulness and proposals for improvement of the bicycle model}

Many of the climate education experts highlighted the need for models in their work within sustainability education. Compared to Joy Palmer's tree model of environmental education (Palmer 1998), the bicycle model is updated especially with the ideas of future orientation, operational barriers of activity, and hope and other emotions. According to recent research, current news, and the general atmosphere in society, these aspects of education are more and more important.

Material for proposals to improve the bicycle model was gathered first from a seminar discussion group and then from the experts who answered the questionnaire. In both cases, the participants were asked to analyze the need for and usefulness of the model in education and suggest ideas on how to develop it further.

Based on the seminar discussions and the questionnaire, it is fair to say that the participants were excited about the model and found it useful not only for climate change education, but also other for environmental education situations. Some of the participants also mentioned that after studying the model they got ideas how to use it in their work. According to the feedback, the bicycle model also creates many symbolic ideas and awakens inspiration and imagination.

A more detailed analysis of the data shows that suggestions on improving the model can be categorized into three groups: i) the number of parts in the bicycle and their relation to each other, ii) the role of the cyclist and the cyclist's community (participation), and iii) the role of supporting infrastructure (support for climate change educators). These are presented below in further detail.

Some of the respondents considered the bicycle model to be too complicated and would have preferred fewer components. However, the experts could not unequivocally 
mention which parts of the model were useless, though barriers of climate change reached some level of consensus, as mentioned above. It was also pointed out that some of the parts of the model overlap. Indeed, as a model that aims to depict something holistic, this is unavoidable: All the parts are in relation to the others and have an impact as a whole, and thus, removing one component completely may not be sensible. For example, experts pointed out that socio-emotional aspects of denial and indifference are included in the aspects of hope and other emotions, as well as in action. Similarly, dealing with climate change mitigation is related to the aspects of knowledge, thinking skills and values, identity and worldview. However, as these components have much more to them, combining them into a single category does not help communicate the distinct nature of each.

One concrete way to develop the model suggested by experts would be to add a bell. This could depict making noise or lobbying and drawing attention to climate change education in our society. Another expert brought out how climate change education has developed in a similar way to the history of bikes: Originally bikes were equipped with a big front wheel. Similarly, climate change education used to have a strong focus on only one wheel of the bike: knowledge. Continuing this line of thought, experts in the discussion group pointed out that nowadays climate change education needs to be adjusted for different educational styles and situations. As we have a wide array of bikes ranging from tricycles to tandem bikes, maybe several models for climate change education are also needed.

According to experts, one of the main disadvantages of the model is the lack of social and societal aspects. Though these aspects are implicitly present in the model in components such as knowledge, motivation. and action, they could be emphasized by modifying the bicycle. The experts suggested several ways to do so. Some suggested creating a tandem version of the model or adding a seat or a trailer that could carry a co-passanger. Experts also suggested that these aspects could be depicted by adding something outside the model itself: a 
globe could depict the global challenge or other bikers could represent everyone in society needing climate change education. Experts went as far as to consider bringing forth ideologies and prevailing power relations in the bikers: 'Prevailing power relations and ideologies guide people's action related to climate change. One possible interpretation is that by using the bicycle model, one could evaluate what kind of biking glasses the driver is wearing and who are the sponsors visible on the biking vest (prevailing power relations). This would promote understanding the drivers of others' actions.' (E14)

Finally, experts stressed that the model could be advanced by depicting how to support climate and environmental educators. Someone suggested that the model could include service spots and equipment for cyclists. This would symbolize that people who do climate change education work sometimes need help, support, and strengthening. One participant in the group discussion also mentioned how important it was for environmental educators - and cyclists, too- to occasionally take a break and rest.

\section{Discussion and conclusions}

The bicycle model described in this article is based on a large amount of research on climate change education (see Tolppanen et al., 2017). The model was created to depict the holistic nature of climate change education and to highlight how different aspects of it are interconnected. The data for this research was gathered in one country, Finland. Gathering experiences and data in other countries as well would add to the reliability of the model and further test its usefulness. This is an aim for further research.

As the results show, using the bicycle metaphor helps demonstrate the complex nature of climate change education and, more widely, sustainability education. Some informal discussions with experts have pointed out that the model has already helped them formulate a structure for lectures on climate education. The model has also been used as an evaluation 
tool for an in-service teacher training course about Agenda 2020 goals. In this instance, the tool was used to examine the themes and content of the course: Were there elements of knowledge and thinking skills? How were the course participants' worldviews and values taken into account in course activities? Were there various kinds of action and group work to motivate the participants? Were the perspectives of future and emotions in the course themes? With this same evaluation idea, the model can be used as a tool to develop teacher education courses, examine classroom practice when dealing with climate education, and evaluate how curricula meet the needs of climate change education.

The results of this study show that experts consider the model as a useful contribution to climate change education, and though the model has its shortcomings, experts found it to excite them and ignite new thoughts on the nature of climate change education. The model is also a rich pedagogical reflection on what should be prioritized and considered in the field of sustainability. As an example, one university lecturer described how recently in her class, some students started to cry during a lecture on sustainability issues. The teacher said that previously her lectures were mostly packed with scientific knowledge, but now she needs to consider additional aspects of climate education, such as her students' emotions. The bicycle model can help teachers remember different aspects of climate education in planning and teaching.

Though the model was created primarily for climate change education, the findings indicate that it could also be applied more broadly to sustainability and environmental education. This was a somewhat surprising result, as this was not the aim when creating the model. In fact, the model was created because current models were not specific enough to climate change education, and so it was thought that the new model would have specifics that did not apply to sustainability or environmental education as a whole. However, although the current models of environmental education do not meet the needs of climate change 
education, this does not mean that the reverse cannot be true. Many environmental issues deal with the same multifaceted, multidisciplinary challenges as climate change, which previous models have partially failed to capture. As the bicycle model depicts these dimensions (for instance, hope and other feelings) in a coherent way, the model may also be useful to other challenges faced in environmental and sustainability education and beyond.

Of course, not all aspects of the model are as strongly present in all areas of sustainability or environmental education as they are in climate change education, but the participants in this study seemed to agree that the model is applicable. For instance, when dealing with issues such as energy use, many of the dimensions of the bicycle model (such as values, action, etc.) need to be addressed in education.

The findings also indicate several ways the model could be improved. Most notably, some experts view dealing with barriers of climate change as nonessential and therefore could even be omitted from the model. However, the authors do not think that this aspect should be removed from the model for three reasons. The main reason is that there is evidence that when people become aware of the barriers in their behavior, they have a more realistic possibility to change it (Cantell \& Larna 2005). Also, understanding common barriers can help people understand each other, our shortcomings, and how we can move forward together. In addition, some of these barriers may be self-evident, increasing the importance of discussing them in climate change education.

Furthermore, dealing with barriers of climate change also has an important societal impact. After the IPCC report was published in autumn 2018, a new kind of discussion began among politicians, scientists, and economists about the solutions to climate change problems in societies. In this discussion, it has been obvious that people compare and value proposed solutions and also consider the barriers of decisions and people's behavior. For example, it is 
necessary to understand why people refuse to use public transport: Is it because of failed planning, long walking distances, laziness and comfort, price, or something else?

The second way the model could be developed is to enhance the social and societal aspect of climate change education. This could be depicted by drawing another bicycle and cycling infrastructure behind and around the current bicycle. It was also suggested that social aspects could be enhanced by creating a tandem model of the bicycle. Though developing the model in this direction is intriguing, a tandem bicycle has its own shortcomings. For instance, it is hard to ride a tandem bike alone, though sometimes that may be necessary. Furthermore, it takes away from the autonomy of being in control of your own bike. People are motivated by different things and may prefer to take different types of mitigating actions. A tandem takes away autonomy to do those actions one sees as most suitable. Nonetheless, the social and societal aspect of climate change education is essential and the authors suggest this could be best depicted by drawing several bikes side by side.

In all, the model seems to be a good depiction of climate change education and can probably be applied to many instances. One area where the model could be especially helpful is in teacher education. When planning lessons and learning modules on climate change, the model can help pre- and in-service teachers to reflect on their own teaching practices and to analyze how holistic their teaching is. For instance, teachers could reflect on whether their classroom practice supports taking mitigative action and whether they have the means to deal with students' emotions, such as anxiety. In addition, the model can be used in curriculum revision and development. It is also a useful tool when evaluating courses in the area of sustainability education.

Furthermore, the model can work as a useful tool to conceptualize the contents of one's own learning. The ultimate goal — and challenge — is to promote holistic climate change education and strengthen sustainability in our planet. 


\section{References}

Aarnio-Linnanvuori, E. 2016. 'Ympäristöaiheiden tieteidenvälisyys yleissivistävän opetuksen haasteena aineenopettajien näkökulmasta' [Interdisciplinarity of environmental issues as a challenge in general education according to subject teachers]. Kasvatus \& Aika 2016 (2): 3350.

Aarnio-Linnanvuori, E. 2018. Ympäristö ylittää oppiainerajat - arvolatautuneisuus ja monialaisuus koulun ympäristöopetuksen haasteina [Environment crosses subject borders Being value-laden and interdisciplinarity as challenges for environmental education at school]. Environmentalica Fennica 34. Helsinki: University of Helsinki.

Andersson, B. and A. Wallin. 2000. 'Students' understanding of the greenhouse effect, the societal consequences of reducing $\mathrm{CO} 2$ emissions and the problem of ozone layer depletion.' Journal of Research in Science Teaching 37 (10): 1096-1011.

Andrey, J. and L. Mortsch. 2000. 'Communicating about climate change: Challenges and opportunities. In Climate change communication: Proceedings from an international conference, 1-11. Kitchener-Waterloo: University of Waterloo and Environment Canada. Cantell, H. and R. Larna. 2006. Ympäristövastuullisuus nuorten sanoissa ja teoissa [Environmental responsibility in young people's words and deeds]. Helsingin kaupungin opetusviraston julkaisusarja A1:2006. Helsinki: Helsingin kaupungin opetusvirasto. Degerman, L. 2016. Elever och klimatförändringen. En enkätundersökning bland finlandssvenska och svenska niondeklassare [Pupils and climate change. A survey study among Swedish speaking Finnish and Swedish ninth graders]. Åbo: Åbo Akademis förlag. Gifford, R. 2011. 'The dragons of inaction. Psychological barriers that limit climate change mitigation.' American Psychologist 66 (4): 290-302. 
González-Gaudiano, E., and P. Meira-Cartea. 2010. 'Climate change education and communication.' In Education and climate change: Living and learning in interesting times, edited by F. Kagawa, F. and D. Selby, 13-34. New York: Routledge.

Hens, L. and S. Stoyanov. 2013. 'Education for climate changes, environmental health and environmental justice.' Journal of Chemical Technology and Metallurgy 49 (2): 194-208. Hermans, M. 2016. 'Geography teachers' and climate change: Emotions about consequences, coping strategies, and views on mitigation.' International Journal of Environmental and Science Education 11 (4): 389-408.

Hicks, D. 2014. Educating for hope in troubled times: Climate change and the transition to a post-carbon future. London: Institute of Education Press.

Hungerford, H. R., and T. L. Volk. 1990. 'Changing learner behavior through environmental education.' The Journal of Environmental Education 21 (3): 8-21. Incropera, F. P. 2015. Climate change: A wicked problem - Complexity and uncertainly at the intersection of science, economics, politics and human behaviour. Cambridge: Cambridge University Press.

Kallgren, C. A. and W. Wood. 1986. 'Access to attitude-relevant information in memory as a determinant of attitude-behavior consistency.' Journal of Experimental Social Psychology 22 (4): $328-338$.

Kollmuss, A. and J. Agyeman. 2002. 'Mind the gap: Why do people act environmentally and what are the barriers to pro-environmental behavior?' Environmental Education Research 8 (3): 239-260.

Koskinen, S. and R. Paloniemi. 2009. 'Social learning processes of environmental policy'. In Handbook of Environmental Policy, edited by J. Meijes and A. der Berg, 291-305. New York: Nova Science Publishers. 
Lehtonen, A. and H. Cantell. 2015. Ilmastokasvatus osaamisen ja vastuullisen kansalaisuuden perustana. [Climate change education as a basis of understanding and responsible citizenship]. Suomen ilmastopaneelin raportteja 1/2015.

Lombardi, D. and G. M. Sinatra. 2013. 'Emotions about teaching about human-induced climate change.' International Journal of Science Education 35 (1): 167-191.

Lombardi D., G. M. Sinatra, and E. M. Nussbaum. 2013. 'Plausibility reappraisals and shifts in middle school students' climate change conceptions.' Learning and Instruction 27, 50-62. Lonka, K., L. Hietajärvi, R. Hohti, M. Nuorteva, A-P. Rainio, N. Sandström, L. Vaara., and S. K. Westling. 2015. 'Ilmiölähtöisesti kohti innostavaa oppimista' [A phenomenon-based way towards rousing learning]. In Näin rakennat monialaisia oppimiskokonaisuuksia [How to build interdisciplinary learning modules] edited by H. Cantell, 49-76. Jyväskylä: PSkustannus.

MacMillan, E. and L. Vasseur. 2010. 'Environmental education: interdisciplinarity in action.' The International Journal of Interdisciplinary Social Sciences 5 (3): 435-445.

Norgaard, Kari Marie. 2011. Living in denial: Climate change, emotions, and everyday life. MIT Press.

Ojala, M. 2015. 'Hope in the face of climate change: Associations with environmental engagement and student perceptions of teachers' emotion communication style and future orientation.' The Journal of Environmental Education 46 (3): 133-148.

Orr, D. W. 2009. Down to the wire: Confronting climate collapse. Oxford University Press. Palmer, J. A. 1998. Environmental education in the 21st century: theory, practice, progress and promise. London: Routledge.

Pihkala, P. 2017. 'Environmental Education After Sustainability: Hope in the midst of Tragedy.' Global Discourse 7 (1): 109-127. 
Ratinen, I. J. 2013. 'Primary student-teachers' conceptual understanding of the greenhouse effect: a mixed method study.' International Journal of Science Education 35 (6), 929-955. Ratinen, I. 2016. Primary student teachers' climate change conceptualization and implementation on inquiry-based and communicative science teaching: A design research. Jyväskylä Studies in Education, Psychology and Social Research. Jyväskylä: University of Jyväskylä.

Salonen, A. 2010. Kestävä kehitys globaalin ajan hyvinvointiyhteiskunnan haasteena [Sustainable development and its promotion in a welfare society in a global age]. Tutkimuksia 318. Helsinki: Yliopistopaino.

Schreiner, C., E. Henriksen, \& P. J. K. Hansen. 2005. 'Climate education: Empowering today's youth to meet tomorrow's challenges.' Studies in Science Education 41 (1), 3-49. Selby, D. 2010. 'Go, go, go, said the bird': Sustainability-related education in interesting times.' In Education and Climate Change: Living and Learning in Interesting Times, edited by F. Kagawa and D. Selby, 35-54. New York: Routledge.

Shepardson, D. P., D. Niyogi, A. Roychoudhury, and A. Hirsch. 2012. 'Conceptualizing climate change in the context of a climate system: Implications for climate and environmental education.' Environmental Education Research 18 (3): 323-352.

Snyder, C. R., K. L. Rand, and D. R. Sigmon. 2002. Hope theory: A member of the positive psychology family. In Handbook of positive psychology, edited by C. R. Snyder and S. J. Lopez, 257-276. Oxford: Oxford University Press.

Sterling, S. 2010. Learning for resilience, or the resilient learner? Towards a necessary reconciliation in a paradigm of sustainable education. Environmental Education Research, 16(5-6), pp.511-528. 
Tirri, K., S. Tolppanen, M. Aksela, and E. Kuusisto. 2012. ‘A Cross-cultural Study of Gifted Students' Scientific, Societal and Moral Questions Concerning Science.' Education Research International, 2012, [673645].

Tolppanen, S. 2015. Creating a better world: questions, actions and expectations of international students on sustainable development and its education. Helsinki: University of Helsinki.

Tolppanen, S. and M. Aksela. 2018. 'Identifying and addressing students' questions on climate change.' The Journal of Environmental Education.

DOI:10.1080/00958964.2017.1417816

Tolppanen, S., Cantell, H., Aarnio-Linnanvuori, E. \& Lehtonen, A. 2017. Pirullisen ongelman äärellä - kokonaisvaltaisen ilmastokasvatuksen malli [Dealing with a wicked problem - a model for holistic climate change education]. Kasvatus, 5/2017, p. 456-468.

Uitto, A., J. Boeve-de Pauw. \& S. Saloranta. 2014. 'Educational factors explaining 9th graders self-efficacy in ecological sustainable behaviours.' In E-Book Proceedings of the ESERA 2013 Conference: Science Education Research For Evidence-based Teaching and Coherence in Learning. Part 9 (co-ed. Graca Garvalho and Marianne Mortensen Foss) Strand 9: Environmental, health and outdoor science education. European Science Education Research Association ESERA.

Wise, S. B. 2010. 'Climate Change in the Classroom: Patterns, Motivations, and Barriers to Instruction among Colorado Science Teachers.' Journal of Geoscience Education 58 (5), 297-309. 